\title{
JURNAL ORGANISASI DAN MANAJEMEN
}

Issue 1 (Agustus, 2018)

\section{Pengaruh Pelatihan dan Motivasi Kerja Terhadap Produktivitas Kerja Pegawai}

\author{
Andi Pettarani 1), Herman Sjahruddin 2), Abd. Mansyur Mus ${ }^{3)}$ \\ Andipettarani43@gmail.com
}

1) Mahasiswa Program Studi Manajemen pada Sekolah Tinggi Ilmu Ekonomi Bongaya Makassar

2,3) Dosen Program Studi Manajemen pada Sekolah Tinggi Ilmu Ekonomi Bongaya Makassar

\begin{abstract}
ABSTRAK
Penelitian ini bertujuan untuk menguji dan menganalisis pengaruh pelatihan dan motivasi kerja Terhadap Peningkatan Produktivitas Pegawai Badan Pusat Statistik (BPS) Provinsi Sulawesi Selatan. Populasi dalam penelitian ini seluruh pegawai pada badan pusat statistik (BPS) Provinsi Sulawesi Selatan yang berjumlah 88 pegawai. Analisis regresi berganda digunakan dalam menguji hipotesis penelitian dengan menggunakan Statistical Package for the Social Sciences (SPSS) versi, 21.0. Hasil penelitian memberikan bukti bahwa pelatihan berpengaruh positif tidak signifikan terhadap produktivitas kerja, pada pengujian lainnya dibuktikan bahwa motivasi kerja berpengaruh positif signifikan terhadap produktivitas kerja pegawai.
\end{abstract}

Kata kunci : Pelatihan, motivasi kerja, produktivitas kerja pegawai

\begin{abstract}
Regression analysis is constructed for capturing the effect of of training and work motivation on the employee productivity of South Sulawesi Central Bureau of Statistics (BPS). The population in this study were all employees of the South Sulawesi statistics center (BPS) totaling 88 employees. Multiple regression analysis was used to test the research hypothesis using Statistical Package for the Social Sciences (SPSS) version, 21.0. The results of the study provide evidence that the training has insignificant positive effect on work productivity, in other tests proved that the work motivation has a significant positive effect on employee productivity
\end{abstract}

Keywords: $\quad$ Training, work motivation, employee work productivity 


\section{JURNAL ORGANISASI DAN MANAJEMEN}

Issue 1 (Agustus, 2018)

\section{Latar Belakang}

Kunci kesuksesan organisasi/instansi sangat di tentukan oleh, salah satunya adalah kualitas kerja pegawai. Penciptaan kualitas kerja Aparatur Sipil Negara yang maksimum dapat diperoleh melalui keterlibatan Aparatur Sipil Negara dalam pelaksanaan program pelatihan. Pelatihan merupakan suatu usaha yang dilakukan instansi untuk meningkatkan pengetahuan (knowledge) dan keahlian (skill) (Flippo ; dalam Suwanto dan Priansa, 2011).

Pelatihan yang dilakukan Badan Pusat Statistik Provinsi Sulawesi Selatan bertujuan untuk meningkatkan produktivitas kerja Aparatur Sipil Negara, melalui pelatihan Aparatur Sipil Negara diberikan berbagai jenis materi pelatihan untuk meningkatkan kinerjanya pada ruang lingkup masingmasing, salah satunya adalah Pelatihan Fungsional di Bidang Kepranataaan Komputer. Pranata Komputer adalah Aparatur Sipil Negara Negeri Sipil yang diberi tugas, tanggung jawab, wewenang, dan hak secara penuh oleh pejabat yang berwenang untuk melakukan kegiatan di bidang teknologi informasi berbasis komputer, antara lain analis sistem, programmer, operator data entry, teknisi komputer, administrator jaringan, administrator data base, dan perancang website (situs).

Bentuk pelatihan yang dilakukan tersebut di atas bertujuan untuk meningkatkan kualitas pendataan, kesesuaian dengan prosedur kerja, dan batas waktu yang telah ditetapkan. Pelatihan sangat penting untuk dilaksanakan bagi kepentingan bersama, sebab dari sinilah para karyawan akan dapat lebih memahami dan mengerti tentang tugas dan tanggung jawab yang di emban baik secara individu maupun kelompok (Kaswan, 2011).

Fakta lapangan yang diperoleh setelah dilakukannya pra-penelitian menunjukkan bahwa tugas utama Badan Pusat Statistik (BPS) adalah untuk menyediakan kebutuhan data bagi pemerintah dan masyarakat, namun faktanya pihak BPS sering kali mengalami keterlambatan dalam menyediakan data yang dibutuhkan, hal ini disebabkan salah satunya karena belum optimalnya dalam memanfaatkan dan menggunakan teknologi Computer.

Pada bahagian lainnya ditemukan penyebab keterlambatan BPS dalam menyediakan data bagi pemerintah dan masyarakat disebabkan oleh faktor individual berupa rendahnya motivasi kerja Aparatur Sipil Negara dalam menjalankan tugas dan fungsinya disebabkan karena pemberian balas jasa dalam bentuk tunjangan kinerja tidak dilakukan secara adil dan transparan sehingga berdampak terhadap rendahnya kemampuan Aparatur Sipil Negara dalam melakukan tugasnya dan kemudian berdampak terhadap rendahnya produktivitas Aparatur Sipil Negara.

Produktivitas kerja Aparatur Sipil Negara adalah bagaimana menghasilkan atau meningkatkan hasil barang dan jasa setinggi mungkin dengan memanfaatkan sumber daya secara efisien. Produktivitas merupakan perbandingan antara output dengan input perusahaan,industri dan ekonomi secara keseluruhan (Sedarmayanti, 2009). Produktivitas Aparatur Sipil Negara atau yang disebut dengan kinerja individual Berdasarkan teorinya merupakan fungsi dari kemampuan, usaha dan dukungan yang individu dan organisasi (Mathis dan Jackson, 2001) teori tersebut dapat dikemukakan dengan persamaan: $($ kinerja/produktivitas $=f(\mathrm{~A} \times \mathrm{E} \times \mathrm{S})$ di mana faktor $(\mathrm{A})$

Halaman 67

Authors : Andi Pettarani dkk. Issue 1 (Agustus, 2018); 66 81 
adalah kemampuan yang dimiliki oleh Aparatur Sipil Negara, seperti rekrutmen, seleksi dan pelatihan yang merupakan yaitu kemampuan alami dengan memilih orang berbakat dan memiliki minat yang tepat dengan pekerjaan yang diberikan. Faktor (E) merupakan usaha yang dilakukan seseorang yang dipengaruhi oleh masalah sumber daya manusia, seperti motivasi, insentif dan rancangan pekerjaan. Faktor (S) merupakan dukungan organisasi seperti, pelatihan, konsistensi manajemen, pengembangan karier karyawan yang jelas dan adil, peralatan yang disediakan memadai dan harapan.

Berdasarkan teori tersebut maka dapat dinyatakan bahwa produktivitas kerja Aparatur Sipil Negara dipengaruhi oleh dua faktor yaitu, yaitu Faktor usaha (Effort)yang merupakan usaha yang dicurahkan oleh Aparatur Sipil Negara dan ditunjukkan dengan motivasi kerja Aparatur Sipil Negara. Selanjutnya yaitu Faktor dukungan (Support) merupakan dukungan organisasi yang ditunjukkan Dalam bentuk pelatihan.

Temuan peneliti terdahulu yang menganalisis tentang pengaruh pelatihan yang diukur dengan pengukuran yang digunakan Mangkunegara (2009) dalam Komara dan Luwis, (2017), meliputi: instruktur pelatihan, peserta, materi pelatihan, metode pelatihan dan tujuan. Hasil penelitian tersebut memberikan bukti bahwa pelatihan berpengaruh positif dan signifikan terhadap produktivitas kerja (Budiartha dkk., 2015;Komara dan Luwis, 2017) Bukti tersebut memperoleh bantahan dari peneliti lainnya bahwa, pelatihan tidak signifikan pengaurnya terhadap kinerja karyawan sebagai perwujudan dari produktivitas kerja (Safitiri, 2013).

Faktor pelatihan tidak dapat berdiri sendiri, dibutuhkan pula kontribusi faktor lainnya yaitu faktor motivasi kerja. Motivasi kerja adalah kesediaan individu untuk mengeluarkan upaya yang tinggi untuk mencapai tujuan organisasi. Dengan motivasi kerja diharapkan setiap karyawan dapat membangkitkan keinginan untuk bekerja keras dan antusias untuk mencapai produktivitas kerja yang tinggi (Hasibuan, 2010). Fakta lapangan yang diperoleh pada saat dilakukannya pra-penelitian memberikan bukti bahwa pada motivasi kerja yang di miliki oleh beberapa orang Aparatur Sipil Negara cenderung rendah, hal ini dapat dilihat dari rendahnya tingkat absensi Aparatur Sipil Negara, disiplinitas kerja Aparatur Sipil Negara yang tergolong rendah serta rendahnya ketaatan Aparatur Sipil Negara dalam mematuhi prosedur pelaksanaan dan penyelesaian pekerjaan.

Temuan peneliti terdahulu yang menganalisis pengaruh motivasi terhadap produktivitas kerja yang mengukur dengan membagi motivasi kerja ke dalam 2 (dua) dimensi, yaitu motivasi intrinsik dan motivasi ekstrinsik Soeroso, (2003) dalam Alimuddin (2015) dimana, Motivasi Ekstrinsik adalah dorongan kerja yang timbul dari luar masing-masing Aparatur Sipil Negara, yang indikatornya meliputi: kebutuhan sosial, pemberian fasilitas, dan kepemimpinan. Pada dimensi lainnya yaitu Motivasi intrinsik yang merupakan dorongan atau keinginan yang kuat yang berasal dari dalam diri seseorang yang indikatornya meliputi: pemberian gaji, rasa aman, penghargaan, dan pengembangan potensi Aparatur Sipil Negara atau aktualisasi diri. Hasil penelitian tersebut memberikan bukti bahwa motivasi kerja pada dimensi motivasi intrinsik berpengaruh negatif dan tidak signifikan terhadap

Halaman 68 


\section{JURNAL ORGANISASI DAN MANAJEMEN}

Issue 1 (Agustus, 2018)

produktivitas kerja karyawan, sedangkan motivasi kerja pada dimensi ekstrinsik berpengaruh positif dan signifikan terhadap produktivitas kerja karyawan. Hasil tersebut berbeda dengan temuan peneliti lainnya, bahwa motivasi kerja berpengaruh positif signifikan terhadap produktivitas kerja Aparatur Sipil Negara (Budiartha dkk., 2015).

\section{Tinjauan Teoritis}

\section{Pelatihan (Training)}

Pelatihan sebagai salah satu upaya untuk meningkatkan produktivitas kerja karyawan. Karena perkembangan perusahaan harus diimbangi dengan produktivitas kerja karyawan yang tinggi, sehingga ini akan meningkatkan pengetahuan dan keterampilan serta kemampuan karyawan agar dapat melaksanakan suatu tugas atau pekerjaan yang dibebankan kepadanya secara efektif dan efisien. Pelatihan Aparatur Sipil Negara adalah setiap usaha untuk memperbaiki performa pekerja pada suatu pekerjaan tertentu yang sedang menjadi tanggung jawabnya atau satu pekerjaan yang ada kaitannya dengan pekerjaan (Sunyoto 2012 :137).

Faktor-faktor Perlunya diselenggarakan program pelatihan dan pengembangan menurut Sedarmayanti, (2013:167) di antaranya yaitu : (1) Adanya Aparatur Sipil Negara baru, (2) Aparatur Sipil Negara yang ditempatkan pada pekerjaan lama, (3) Kurang persiapan dalam mengangkat Aparatur Sipil Negara baru, (4) Fasilitas baru diberikan dalam kegiatan tertentu (5) Penemuan atau alat dan cara baru, (6) Pengawas, administrator. Hubungan dengan kantor lain dan dengan masyarakat. Pelatihan diharapkan meningkatkan keahlian kerja yang dimiliki oleh setiap Aparatur Sipil Negara. Mangkunegara (2009:46) menjelaskan bahwa pengukuran meliputi beberapa indikator, yaitu : (1) Instruktur (2) Peserta pelatihan (3) Materi pelatihan (4) Metode pelatihan (5)Tujuan pelatihan (6) Sasaran pelatihan

\section{Motivasi kerja}

Motivasi kerja adalah sesuatu yang menimbulkan dorongan atau semangat kerja atau dengan kata lain pendorong semangat kerja (Martoyo, 2007). Sedangkan Robbins dan Judge (2008) menyatakan bahwa motivasi adalah proses yang berperan pada intensitas, arah dan lamanya berlangsung upaya individu ke arah pencapaian sasaran.

Motivasi melibatkan faktor-faktor individu dan faktor-faktor organisasi. Faktor-faktor yang sifatnya individu adalah kebutuhan, tujuantujuan, sikap dan kemampuan. Sedangkan yang tergolong pada faktor-faktor yang berasal dari organisasi meliputi pembayaran atau gaji, keamanan pekerja, pengawasan, pujian dan pekerjaan itu sendiri. Individu akan bersedia bekerja keras dengan harapan ia akan dapat memenuhi kebutuhan dan keinginan-keinginannya dari hasil pekerjaannya. Sejalan dengan hal itu Peterson dan Plowman (dalam Martoyo, 2007) mengatakan bahwa yang dimaksud keinginan dalam penjelasan tersebut adalah (1) The desire to live, artinya keinginan untuk hidup merupakan keinginan utama dari setiap orang; manusia bekerja untuk dapat makan dan makan untuk dapat

Halaman 69

Authors : Andi Pettarani dkk. Issue 1 (Agustus, 2018); 66 81 


\section{JURNAL ORGANISASI DAN MANAJEMEN}

Issue 1 (Agustus, 2018)

melanjutkan hidupnya. (2) The desire for posession, artinya keinginan untuk memiliki sesuatu merupakan keinginan manusia yang kedua dan ini salah satu sebab mengapa manusia mau bekerja. (3) The desire for power, artinya keinginan akan kekuasaan merupakan keinginan selangkah di atas keinginan untuk memiliki, mendorong orang mau bekerja. Penelitian ini menggunakan pengukuran Soeroso, (2003) dalam Alimuddin (2015) membagi motivasi ke dalam 2 (dua) dimensi yaitu intrinsik dan ekstrinsik dengan mengukur motivasi menggunakan indikator : (1) Motivasi intrinsic meliputi : Gaji, Rasa aman, Penghargaan, Pengembangan potensi. (2) Motivasi Ekstrinsik meliputi :Kebutuhan, Pemberian fasilitas, Kepemimpinan

\section{Produktivitas kerja}

Produktivitas kerja adalah kemampuan menghasilkan barang dan jasa dari berbagai sumber daya atau faktor produksi yang digunakan untuk meningkatkan kualitas dan kuantitas pekerjaan yang dihasilkan dalam suatu organisasi (Hartatik, 2014:209). Produktivitas kerja sebagai perbandingan antara output (hasil) dengan input (masukan) (Hasibuan, 2007:126). Jika produktivitas kerja naik ini hanya dimungkinkan oleh adanya peningkatan efisiensi (waktu, bahan dan tenaga) dan sistem kerja, teknik produksi dan adanya peningkatan keterampilan dari tenaga kerjanya. Faktor-faktor yang mempengaruhi Produktivitas kerja yang tinggi hanya dapat dicapai dengan adanya perpaduan usaha antara organisasi dan anggota organisasi, melalui (1)Pelatihan, (2) Mental dan kemampuan fisik karyawan, (3) Hubungan antara atasan dan bawahan (Sedarmayanti, 2009:102). Penelitian ini menggunakan pengukuran produktivitas yang digunakan (Saksono, 2008), yaitu: (1) Tingkat absensi yang tinggi (2) Tingkat pencapaian hasil. (3) Kualitas yang dihasilkan (4) Tingkat kesalahan. (5) Waktu yang dibutuhkan

\section{Metode Penelitian}

Jenis penelitian ini adalah data kuantitatif, yang diperoleh melalui instrumen penelitian (kuesioner), data kuantitatif adalah data yang penekanannya pada data angka-angka (numerical) yang diolah dengan metode statistika (Fauzi, 2009). Sampel sejumlah 88 Pegawai. Analisis data penelitian ini menggunakan analisis regresi berganda dengan bantuan Statistical Package for the Social Sciences (SPSS) versi, 21. Teknik pengumpulan data dalam penelitian ini yaitu : observasi dan kuesioner. Pengukuran variabel dalam penelitian ini yang diukur menggunakan Skala Ordinal dengan menggunakan Skala Likert, skor 1 untuk jawaban sangat tidak setuju (STS), skor 2 untuk jawaban tidak setuju (TS), skor 3 untuk jawaban netral (N), skor 4 untuk jawaban setuju (S), dan untuk skor 5 untuk jawaban sangat setuju (SS).

\section{Hasil Penelitian}

1. Hasil Uji Instrumen

Uji instrumen penelitian digunakan untuk menguji tingkat keakuratan data dalam pengujian hipotesis. Sehingga dalam uji instrumen diterapkan uji validitas dan reliabilitas.

Authors : Andi Pettarani dkk. Issue 1 (Agustus, 2018); 66 81 


\section{JURNAL ORGANISASI DAN MANAJEMEN}

Issue 1 (Agustus, 2018)

\section{a. Uji Validitas}

Pengujian validitas dilakukan berdasarkan analisis item yaitu mengkorelasikan skor setiap item dengan skor variabel. Suatu instrumen yang valid atau sahih mempunyai validitas tinggi, sebaliknya instrumen yang kurang valid berarti memiliki validitas yang rendah . Jika nilai person correlation $(r=>0.30)$ dan tingkat signifikansinya $(\alpha=<0.05)$ maka instrumen atau item-item pertanyaan berkorelasi signifikan terhadap skor total (dinyatakan valid). Tabel di bawah ini menunjukkan hasil uji validitas dari tiga variabel dalam penelitian ini yaitu pelatihan $\left(\mathrm{X}_{1}\right)$, motivasi $\left(\mathrm{X}_{2}\right)$, dan produktivitas kerja (Y) :

Tabel 1 Hasil uji validitas Pelatihan/training (X1)

\begin{tabular}{|c|c|c|c|c|c|}
\hline \multirow{4}{*}{ Variabel } & $\begin{array}{c}\text { Dimensi / } \\
\text { Indikator/ } \\
\text { Item }\end{array}$ & $\begin{array}{c}\text { Koefisien } \\
\text { Korelasi }\end{array}$ & Signifikan & $\begin{array}{c}\text { Std. } \\
\text { Correlation }\end{array}$ & Keterangan \\
\hline \multirow{4}{*}{$\begin{array}{c}\text { Pelatihan } \\
\text { (X1) }\end{array}$} & $\mathrm{X} 111$ & 0.885 & 0.00 & & \\
\cline { 2 - 4 } & $\mathrm{X} 112$ & 0.842 & 0.00 & & \multirow{2}{*}{0.30} \\
\cline { 2 - 4 } & $\mathrm{X} 113$ & 0.690 & 0.00 & & \\
\cline { 2 - 4 } & $\mathrm{X} 114$ & 0.767 & 0.00 & & \\
\cline { 2 - 4 } & $\mathrm{X} 115$ & 0.586 & 0.00 & & \\
\cline { 2 - 4 } & $\mathrm{X} 116$ & 0.617 & 0.00 & & \\
\hline
\end{tabular}

Sumber : Data diolah, SPSS Ver.21 (2018)

Pada tabel 1 di atas menunjukkan bahwa seluruh pernyataan dalam variabel Pelatihan telah memenuhi uji validitas terlihat dari nilai koefisien korelasi ( $r$ ) dari setiap pernyataan $>0.30$ dan $\operatorname{sig}<0.05$

Tabel 2. Hasil uji validitas variabel motivasi kerja (X2)

\begin{tabular}{|c|c|c|c|c|c|}
\hline Variabel & $\begin{array}{l}\text { Dimensi / } \\
\text { Indikator/ } \\
\text { Item }\end{array}$ & $\begin{array}{c}\text { Koefisien } \\
\text { Korelasi }\end{array}$ & Signifikan & $\begin{array}{c}\text { Std. } \\
\text { Correlation }\end{array}$ & Keterangan \\
\hline \multirow{4}{*}{$\begin{array}{l}\text { Motivasi } \\
\text { Intrinsik } \\
\text { (X21) }\end{array}$} & $\mathrm{X} 111$ & 0.607 & 0.00 & \multirow{7}{*}{0.30} & \multirow{4}{*}{ Valid } \\
\hline & $\mathrm{X} 112$ & 0.695 & 0.00 & & \\
\hline & $\mathrm{X} 113$ & 0.900 & 0.00 & & \\
\hline & $\mathrm{X} 114$ & 0.879 & 0.00 & & \\
\hline \multirow{3}{*}{$\begin{array}{c}\text { Motivasi } \\
\text { Ekstrinsik } \\
\text { (X22) }\end{array}$} & $\mathrm{X} 211$ & 0.911 & 0.00 & & \multirow{3}{*}{ Valid } \\
\hline & $\mathrm{X} 212$ & 0.915 & 0.00 & & \\
\hline & X213 & 0.906 & 0.00 & & \\
\hline
\end{tabular}

Sumber : Data diolah, SPSS Ver.21 (2018)

Tabel 2 menunjukkan bahwa seluruh pernyataan dalam variabel motivasi kerja telah memenuhi uji validitas terlihat dari nilai koefisien korelasi ( $r$ ) dari setiap pernyataan $>0.30$ dan sig $<0.05$.

Halaman 71

Authors : Andi Pettarani dkk. Issue 1 (Agustus, 2018); 66 81 
Tabel 3. Hasil uji validitas Produktivitas

\begin{tabular}{|c|c|c|c|c|c|}
\hline Variabel & $\begin{array}{c}\text { Dimensi / } \\
\text { Indikator/ } \\
\text { Item }\end{array}$ & $\begin{array}{c}\text { Koefisien } \\
\text { Korelasi }\end{array}$ & Signifikan & $\begin{array}{c}\text { Std. } \\
\text { Correlation }\end{array}$ & Keterangan \\
\hline \multirow{5}{*}{$\begin{array}{l}\text { Produktivitas } \\
\text { (Y) }\end{array}$} & Y11 & 0.789 & 0.00 & \multirow{5}{*}{0.30} & \multirow{5}{*}{ Valid } \\
\hline & Y12 & 0.857 & 0.00 & & \\
\hline & Y13 & 0.857 & 0.00 & & \\
\hline & Y14 & 0.843 & 0.00 & & \\
\hline & Y15 & 0.798 & 0.00 & & \\
\hline
\end{tabular}

Sumber : Data diolah, SPSS Ver.21 (2018)

Tabel 3 menunjukkan bahwa seluruh pernyataan dalam variabel kinerja karyawan telah memenuhi uji validitas terlihat dari nilai koefisien korelasi ( $r$ ) dari setiap pernyataan $>0.30$ dan sig $<0.05$.

\section{b. Uji Reliabilitas}

Instrumen yang reliabel adalah instrumen yang bila digunakan beberapa kali untuk mengukur obyek yang sama, akan menghasilkan data yang sama (Sugiyono; 2014). Setelah instrumen di uji validitasnya maka langkah selanjutnya yaitu menguji reliabilitas. Pengujian reliabilitas dilakukan dengan menggunakan teknik reability analyze dimana suatu instrumen dapat dikatakan reliabel apabila memiliki koefisien cronbach alpha sebesar $=>0,6$. Hasil pengujian realibilitas ini dapat di lihat pada tabel 4 di bawah ini :

Tabel 4. Hasil Uji Reliabilitas

\begin{tabular}{|l|c|c|}
\hline \multicolumn{1}{|c|}{ Variabel } & Cronbach's Alpha & Keterangan \\
\hline Pelatihan (X1) & 0.823 & Reliabel \\
\hline \multirow{2}{*}{ Motivasi (X2) } & 0.839 & Reliabel \\
\cline { 2 - 3 } & 0.925 & Reliabel \\
\hline Produktivitas (Y) & 0.894 & Reliabel \\
\hline
\end{tabular}

Sumber : Data diolah, SPSS Ver.21 (2018)

Berdasarkan hasil pengujian pada tabel 4diatas, maka dapat disimpulkan bahwa variabel dalam penelitian ini telah memenuhi standar uji reliabilitas dengan nilai koefisien reliabilitas setiap variabel penelitian yaitu $>0.60$.

\section{Asumsi Klasik}

Sebuah model regresi dikatakan baik sebagai model empirik jika telah memenuhi serangkaian pengujian Blue (Unbias linear Estimator). Uji BlUE dalam penelitian ini yaitu : 
a. Uji Normalitas

Tabel 5. Hasil Uji Normalitas Data

One-Sample Kolmogorov-Smirnov Test

\begin{tabular}{|ll|r|}
\hline & & \multicolumn{1}{|c|}{ Unstandardized Residual } \\
\hline $\mathrm{N}$ & Mean & 88 \\
Normal Parametersa,b & Std. Deviation & .0000000 \\
& Absolute & .66064694 \\
& Positive & .049 \\
& .049 \\
Most Extreme Differences & Negative & -.043 \\
Kolmogorov-Smirnov Z & & .463 \\
Asymp. Sig. (2-tailed) & & .983 \\
\hline
\end{tabular}

a. Test distribution is Normal.

b. Calculated from data.

Sumber : Data diolah, SPSS Ver.21 (2018)

Tabel 5 menjelaskan bahwa nilai K-S yaitu $0.463>0.05$ serta nilai signifikansi yaitu $0.983>0.05$, maka dapat disimpulkan bahwa data dalam penelitian ini terdistribusi normal. Berdasarkan pengujian formalitas data pada tabel tersebut, hasil pengujian normalitas lainnya dapat di lihat pada gambar di bawah ini:

Gambar 1 Uji Normalitas data

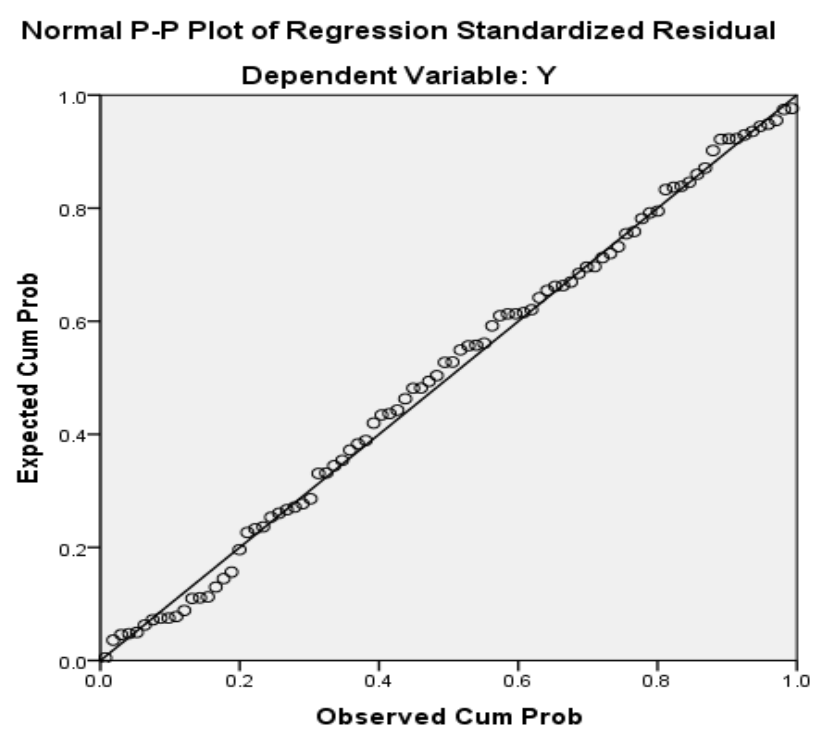

Sumber : Data diolah, SPSS Ver.21 (2018)

Pada gambar 1 menunjukkan bahwa terlihat titik-titik menyebar di sekitar garis diagonal, serta penyebarannya mengikuti arah garis diagonal. Hal ini menunjukkan bahwa model regresi layak dipakai karena asumsi normalitas terpenuhi.

Halaman 73

Authors : Andi Pettarani dkk. Issue 1 (Agustus, 2018); 66 81 
b. Uji Multikoloneritas

Tabel 6. Hasil Uji Multikolonearitas

\begin{tabular}{|c|c|c|c|c|}
\hline \multirow{2}{*}{\multicolumn{2}{|c|}{ Model }} & \multicolumn{2}{c|}{$\begin{array}{c}\text { Standardized } \\
\text { Coefficients }\end{array}$} & \multicolumn{2}{c|}{ Collinearity Statistics } \\
\cline { 3 - 5 } \multicolumn{2}{|c|}{} & Beta & Tolerance & VIF \\
\hline \multirow{3}{*}{1} & (Constant) & & & \\
\cline { 2 - 5 } & $\mathrm{X} 1$ & .109 & .957 & 1.045 \\
\cline { 2 - 5 } & $\mathrm{X} 2$ & .748 & .957 & 1.045 \\
\hline
\end{tabular}

Sumber : Data diolah, SPSS Ver.21 (2018)

Tabel 6 menunjukkan untuk masing-masing variabel yaitu Pelatihan dan Motivasi mempunyai nilai toleransi $0,957>0,10$ dan nilai VIF $1,045<10.0$ maka dapat disimpulkan bahwa tidak terjadi multikolinearitas.

c. Uji Heterokedastisitas

Tabel 7. Hasil Uji Glejser (Heterokedastisitas)

\begin{tabular}{|c|c|c|c|c|}
\hline \multicolumn{5}{|c|}{ Coefficients ${ }^{\mathrm{a}}$} \\
\hline & \multirow[t]{2}{*}{ Model } & $\begin{array}{c}\text { Standardized } \\
\text { Coefficients }\end{array}$ & \multirow[t]{2}{*}{$\mathrm{t}$} & \multirow[t]{2}{*}{ Sig. } \\
\hline & & Beta & & \\
\hline \multirow{3}{*}{1} & (Constant) & & 5.682 & .000 \\
\hline & Pelatihan (X1) & -.194 & -1.807 & .074 \\
\hline & Motivasi (X2) & -.137 & -1.279 & .204 \\
\hline
\end{tabular}

Sumber : Data diolah, SPSS Ver.21 (2018)

Berdasarkan hasil pada tabel 7 menunjukkan bahwa nilai signifikan pada pengujian heterokedastisista untuk variabel Pelatihan yaitu 0.074 $>0.05$, dan variabel Motivasi kerja nilai signifikannya $0.204>0.05$. Berdasarkan pengujian tersebut dapat disimpulkan bahwa model regresi dalam penelitian ini tidak terjadi heterokedastisitas, disebabkan nilai signifikan untuk setiap variabel $>0.05$.

d. Uji Autokorelasi

Tabel 8. Hasil Uji Uji Autokorelasi

Model Summaryb

\begin{tabular}{|c|r|r|r|r|r|}
\hline Model & $\mathrm{R}$ & R Square & $\begin{array}{l}\text { Adjusted R } \\
\text { Square }\end{array}$ & $\begin{array}{c}\text { Std. Error } \\
\text { of the } \\
\text { Estimate }\end{array}$ & $\begin{array}{c}\text { Durbin- } \\
\text { Watson }\end{array}$ \\
\hline 1 & $.77 \mathrm{a}^{\mathrm{a}}$ & .604 & .595 & .66837 & 1.913 \\
\hline
\end{tabular}

a. Predictors: (Constant), X2, X1

b. Dependent Variable: Y

Sumber : Data diolah, SPSS Ver.21 (2018)

Authors : Andi Pettarani dkk. Issue 1 (Agustus, 2018); 66 81 
Berdasarkan hasil pada tabel 8 menunjukkan bahwa hasil uji autokoralasi dengan nilai Durbin Watson (DW) sebesar 1,913 ini akan dibandingkan dengan signifikasi 5\%, jumlah sampel (n) 88, kemudian nilai $\mathrm{k}=2$ dan $\mathrm{n}=88$ (terlampir Tabel Durbin - Watson (DW) pada $\alpha=$ $5 \%)$. sehingga diperoleh nilai batas bawah atau lower bound $(\mathrm{dL})=$ 1.6071 dan nilai batas atas atau upper bound $(\mathrm{dU})=1.6999$. Dasar pengambilan keputusan dalam uji autokorelasi sebagai berikut:

1. Jika nilai DW terletak antara batas atas atau upper bound (du) dan (4 - du), maka koefisien autokorelasi sama dengan nol, berarti tidak ada autokorelasi.

2. Jika nilai DW lebih rendah daripada batas bawah atau lower bound (dl), maka koefisien autokorelasi lebih besar daripada nol, berarti ada autokorelasi positif.

3. Jika nilai DW lebih besar daripada (4 - dl), maka koefisien autokorelasi lebih kecil daripada nol, berarti ada autokorelasi negatif.

4. jika nilai DW terletak di antara batas atas (du) dan batas bawah (dl) ada DW terletak antara (4 - du) dan (4 - dl), maka hasilnya tidak dapat disimpulkan.

5. Jika nilai DW terletak antara (4-du) dan (4 - dl), maka hasilnya tidak dapat disimpulkan.

Nilai Durbin Watson (DW) hitung $=1,913$ nilai ini akan dibandingkan dengan nilai tabel signifikansi $5 \%$, dengan $(n=88)$ dan jumlah variabel independent $(\mathrm{K}=2) \mathrm{dL}=1.6017 \mathrm{dU}=1.6999$. Hasil tersebut menjelaskan bahwa 1.6017 (dL) < 1,913 (DW) <1,6999 (dU). Karena nilai DW > dL dan DW > dU maka dapat disimpulkan bahwa koefisien autokorelasi sama dengan nol, berarti tidak ada autokorelasi positf maupun autokorelasi negatif

\section{Analisis Regresi Ganda}

Hasil pengujian regresi ganda dalam penelitian ini dapat dilihat pada tabel 9 dibawah ini :

Tabel 9. Hasil Uji Regresi berganda

\begin{tabular}{|c|l|r|r|r|r|r|}
\hline \multicolumn{2}{|c|}{} & \multicolumn{2}{|c|}{$\begin{array}{c}\text { Unstandardized } \\
\text { Coefficients }\end{array}$} & $\begin{array}{c}\text { Standardized } \\
\text { Coefficients }\end{array}$ & \multirow{2}{*}{$\mathrm{t}$} & \multirow{2}{*}{ Sig. } \\
\cline { 3 - 5 } \multicolumn{2}{|c|}{ Model } & \multicolumn{1}{|c|}{ B } & Std. Error & Beta & & \\
\hline \multirow{2}{*}{1} & (Constant) & .569 & .287 & & 1.979 & .051 \\
\cline { 2 - 7 } & Pelatihan (X1) & -.120 & .077 & -.109 & 1.558 & .123 \\
\cline { 2 - 7 } & Motivasi (X2) & .699 & .065 & .748 & 10.717 & .000 \\
\hline
\end{tabular}

a. Dependent Variable: Produktivitas

Sumber : Data diolah, SPSS Ver.21 (2018)

Dari hasil pengujian pada tabel 11 diatas, maka dapat disimpulkan hasil dari persamaan dari regresi ganda (Hijrah dkk., 2017) sebagai berikut:

$$
\begin{aligned}
& Y=\alpha+\beta_{1} X_{1}+\beta_{2} X_{2}+e \\
& Y=0,569-0,109 X_{1}+0,748 X_{2}+0,287 e
\end{aligned}
$$

Halaman 75

Authors : Andi Pettarani dkk. Issue 1 (Agustus, 2018); 66 81 


\section{JURNAL ORGANISASI DAN MANAJEMEN}

Issue 1 (Agustus, 2018)

Interpretasi dari model regresi di atas adalah sebagai berikut :

1) Konstanta 0,569, menunjukkan bahwa jika variabel independen pelatihan (training) dan motivasi kerja sama dengan nol, maka Produktivias pegawai akan mengalami peningkatan sebesar 0,569.

2) Koefisien regresi $(-0,109)$ berarti jika variabel pelatihan (X1) turun sebesar satu satuan, maka produktivitas kerja pegawai $(\mathrm{Y})$ akan mengalami penurunan sebesar 0,109 satuan dengan syarat variabel independen lainya tetap.

3) Koefisien regresi $(-0,748)$ berarti jika variabel motivasi kerja (X2) meningkat sebesar satu satuan, maka produktivitas pegawai $(\mathrm{Y})$ akan mengalami peningkatan sebesar 0,812 satuan dengan syarat variabel independen lainya tetap.

4. Uji kelayakan Model (Uji-F)

Penggunaan uji-f dilakukan untuk menilai apakah model yang dibangun telah memenuhi pengujian kesesuaian model ataupun tidak, dasar pengambilan keputusan terpenuhi atau tidaknya kelayakan model yang diajukan yaitu jika nilai $\mathrm{f}_{\text {-hitung }}>\mathrm{f}_{\text {-tabel }}$ dan pada tingkat signifikansi $<0.05$ (Hikmawati, dkk, 2016), maka model yang diajukan dinyatakan telah memenuhi kelayakan pengujian model. Hasil pengujian ini dapat di lihat pada tabel di bawah ini:

Tabel 10. Uji Kelayakan Model (Uji-F)

\begin{tabular}{|c|c|c|c|c|c|c|}
\hline \multicolumn{2}{|c|}{ Model } & $\begin{array}{c}\text { Sum of } \\
\text { Squares }\end{array}$ & df & $\begin{array}{c}\text { Mean } \\
\text { Square }\end{array}$ & F & Sig. \\
\hline \multirow{4}{*}{1} & Regression & 58.011 & 2 & 29.005 & 64.929 & $.000^{\mathrm{b}}$ \\
\cline { 2 - 7 } & Residual & 37.972 & 85 & .447 & & \\
\cline { 2 - 8 } & Total & 95.982 & 87 & & & \\
\hline
\end{tabular}

a. Dependent Variable: Y

b. Predictors: (Constant), X2, X1

Sumber : Data diolah, SPSS Ver.21 (2018)

Hasil pengujian pada tabel 12 menunjukkan bahwa nilai $\mathrm{F}$ (Bahar dan Sjahruddin, 2015) pada nilai df1 dan df2 $=2$, 89, maka $\mathrm{f}$ - tabel di peroleh dari $=$ FINV $(0.05,2,85)$ yaitu sebesar 3,104 , berdasarkan nilai $\mathrm{f}$ tabel tersebut maka dapat disimpulkan bahwa nilai f-hitung lebih besar dari f-tabel $(64,277>3,104)$ dan nilai sig $0.00<0.05$.Sehingga dapat disimpulkan model yang dibangun dapat dilanjutkan ketahapan analisis lanjutan (memenuhi goodnes of fit model), seperti yang ditunjukkan pada gambar nilai $\mathrm{F}$ tabel dibawah ini:

5. Uji-t (Uji Parsial)

Uji-t digunakan untuk mengetahui seberapa jauh pengaruh satu variabel penjelas secara individual dalam menerangkan variasi variabel

Halaman 76

Authors : Andi Pettarani dkk. Issue 1 (Agustus, 2018); 66 81 
terikat. Pengujian melalui uji t adalah dengan t-hitung dan t-tabel pada derajat signifikasi 95\% $(" \alpha "=0,05)$ dengan pengujian dua sisi.

Tabel 11.Uji-t (parsial)

\begin{tabular}{|c|c|c|c|c|c|c|}
\hline \multirow{2}{*}{\multicolumn{2}{|c|}{ Model }} & \multicolumn{2}{|c|}{$\begin{array}{c}\text { Unstandardized } \\
\text { Coefficients }\end{array}$} & \multirow{2}{*}{$\begin{array}{c}\begin{array}{c}\text { Standardized } \\
\text { Coefficients }\end{array} \\
\text { Beta }\end{array}$} & \multirow[t]{2}{*}{$\mathrm{t}$} & \multirow[t]{2}{*}{ Sig. } \\
\hline & & $\mathrm{B}$ & Std. Error & & & \\
\hline \multicolumn{7}{|c|}{1 (Constant) } \\
\hline & & .569 & 287 & & 1.979 & .051 \\
\hline & Pelatihan X1 & -.120 & .077 & -.109 & 1.558 & .123 \\
\hline & Motivasi X2 & .699 & .065 & .748 & 10.717 & .000 \\
\hline \multicolumn{7}{|c|}{ a. Dependent Variable: Y } \\
\hline
\end{tabular}

Sumber : Data diolah, SPSS Ver.21 (2018)

Berdasarkan tabel 11 diatas dapat dilihat yaitu pada nilai $t$ dengan nilai df2 = n-k-1 =89-2-1 = 85, maka $\quad-\quad$ diperoleh pada lampiran yaitu 1,988. Berdasarkan nilai $t$ tabel tersebut maka dapat dilakukan pengujian hipotesis dalam penelitian ini yaitu :

1. Berdasarkan hasil pengujian $t$ dapat disimpulkan bahwa nilai t-hitung lebih kecil dari t-tabel $(1.558<1,988)$ dan nilai signifikan lebih besar dari $0.05(0,123>0.05)$, maka dapat disimpulkan bahwa $\mathrm{H}_{\mathrm{o}}$ diterima dan $\mathrm{H}_{\mathrm{a}}$ ditolak, sehingga hipotesis dalam penelitian ini tolak bahwa Pelatihan (training) berpengaruh positif tidak signifikan terhadap produktivitas kerja pegawai BPS Provinsi Sulawesi Selatan.

2. Berdasarkan hasil pengujian $t$ dapat disimpulkan bahwa nilai t-hitung lebih besar dari t-tabel $(10,717>1,988)$ dan nilai signifikan lebih kecil dari $0.05(0,000>0.05)$, maka dapat disimpulkan bahwa $\mathrm{H}_{\mathrm{o}}$ ditolak dan $\mathrm{H}_{\mathrm{a}}$ diterima, sehingga hipotesis dalam penelitian ini diterima bahwa $\mathrm{H}_{2}$ : Motivasi kerja berpengaruh positif dan signifikan terhadap produktivitas kerja pegawai BPS Provinsi Sulawesi Selatan.

6. Uji Koefisien Determinasi $\left(\mathrm{R}^{2}\right)$

Uji koefisien determinasi ini bertujuan untuk mengetahui persentase besarnya pengaruh variabel independen terhadap kinerja pegawai. Dalam pengujian hipotesis koefisien determinasi dilihat dari besarnya nilai $R$ Square $\left(R^{2}\right)$, untuk mengetahui seberapa jauh variabel bebas berpengaruh terhadap kinerja pegawai. Nilai $\mathrm{R}^{2}$ mempunyai interval 0 sampai $1(0 \leq \mathrm{R} 2 \leq 1)$. Hasil uji determinasi dalam penelitian ini dapat dilihat pada tabel berikut :

Tabel 12 Uji Koefisien Detereminasi $\left(\mathrm{R}^{2}\right)$

\begin{tabular}{ccccc}
\hline Model & $\mathrm{R}$ & $\mathrm{R}$ Square & $\begin{array}{c}\text { Adjusted R } \\
\text { Square }\end{array}$ & $\begin{array}{c}\text { Std. Error of } \\
\text { the Estimate }\end{array}$ \\
\hline 1 & $.777^{\mathrm{a}}$ & 0.604 & 0.595 & 0.66837
\end{tabular}

a. Predictors: (Constant), X2, X1

b. Dependent Variable: Y

Sumber : Data diolah, SPSS Ver.21 (2018)

Halaman 77

Authors : Andi Pettarani dkk. Issue 1 (Agustus, 2018); 66 81 


\section{JURNAL ORGANISASI DAN MANAJEMEN}

Issue 1 (Agustus, 2018)

\section{Interpretasi Hasil Penelitian}

\section{a) Pengaruh Pelatihan (training) terhadap produktivitas kerja}

Pelatihan Aparatur Sipil Negara adalah setiap usaha untuk memperbaiki performa pekerja pada suatu pekerjaan tertentu yang sedang menjadi tanggung jawabnya atau satu pekerjaan yang ada kaitannya dengan pekerjaan (Danang Sunyoto 2012 :137).

Berdasarkan pengujian parsial pada uji-t, menunjukkan bahwa variabel pelatihan (training) berpengaruh positif tidak signifikan terhadap produktivitas kerja pegawai, hasil penelitian ini mengindikasikan bahwa semakin sering pelatihan di berikan kepada pegawai maka akan mampu memberikan kontribusi terhadap tingginya produktivitas kerja pegawai namun kontribusi yang diberikan tidak signifikan atau masih tergolong rendah atau hasil dari pelatihan belum bisa memberikan perubahan yang begitu berarti terhadap peningkatan produktivitas kerja pegawai. Hasil tersebut didukung dengan nilai thitung sebesar $1.558<\mathrm{t}$-tabel sebesar 1.987 dengan nilai signifikan $\mathrm{p}$ value sebesar $0,123>0.05$. Koefisien bertanda positif sebesar 1,558 mengindikasikan bahwa pemberian pelatihan bagi pegawai mampu memberikan kontribusi yang tinggi dibuktikan pada hasil tanggapan responden pada indikator penyelesaian $\left(\mathrm{X}_{111}\right)$ yang menjelaskan Instruktur pelatihan yang saya ikuti memiliki pengetahuan dan kemampuan yang tinggi karena dengan pengetahuan yang luas dan kemampuan yang dimiliki oleh seorang instruktur membuat peserta pelatihan bisa meningkatkan produktivitasnya dalam menyelesaikan pekerjaannya dan mengembangkan keahliannya dalam bekerja.

Pengaruh pelatihan $\left(\mathrm{X}_{1}\right)$ tidak signifikan terhadap produktivitas kerja pegawai disebabkan karena pegawai memiliki kemampuan yang rendah untuk melaksanakan evaluasi pekerjaan. Sehingga dapat disimpulkan bahwa pelaksanaan pelatihan yang diikuti pegawai selama ini belum optimal dirasakan manfaatnya oleh pegawai dalam mendukung proses penyelesaian pekerjaan pegawai. Sehingga berdampak pada rendahnya pemberian beban kerja (proporsi pekerjaan kepada pegawai). Pegawai jarang mengevaluasi hasil dari pekerjaannya sehingga sering terjadi beberapa kesalahan dari hasil kerjaannya. Hal ini dibuktikan pada tanggapan responden pada indikator $\left(\mathrm{Y}_{14}\right)$ yaitu pada pernyataan bahwa Kondisi tersebut dan kuantitas kerja memiliki nilai rata-rata (mean) terendah dibandingkan pernyataan lainnya dalam indikator produktivitas kerja pegawai. Hasil penelitian ini menolak temuan I Gede Novrada Budiartha dkk, (2015) bahwa Pelatihan berpengaruh positif dan signifikan Terhadap Produktivitas Kerja karyawan.

\section{b) Pengaruh Motivasi kerja terhadap produktivitas kerja}

Motivasi kerja adalah sesuatu yang menimbulkan dorongan atau semangat kerja atau dengan kata lain pendorong semangat kerja (Martoyo, 2007). Sedangkan Robbins dan Judge (2008) menyatakan bahwa motivasi adalah proses yang berperan pada intensitas, arah dan lamanya berlangsung upaya individu ke arah pencapaian sasaran. 


\section{JURNAL ORGANISASI DAN MANAJEMEN}

Issue 1 (Agustus, 2018)

Berdasarkan pengujian parsial pada uji $t$, menunjukkan bahwa variabel motivasi kerja berpengaruh positif dan signifikan terhadap kinerja pegawai, hasil penelitian ini mengindikasikan bahwa semakin tinggi motivasi yang diberikan kepada pegawai oleh instansi maka akan mampu memberikan kontribusi atau pengaruh yang signifikan terhadap tingginya produktivitas dalam bekerja.

Hasil tersebut didukung dengan t-hitung sebesar 10.717> t-tabel sebesar 1.988 dengan nilai signifikan p-value sebesar $0.000<$ 0.05.Koefisien yang bertanda positif mengindikasikan bahwa motivasi kerja pada dimensi intrinsik yang diberikan instansi tergolong tinggi hal ini dibuktikan pada hasil tanggapan responden pada indikator penghargaan $\left(\mathrm{X}_{213}\right)$ bahwa responden (pegawai) bahwa Instansi mengapresiasi kepada pegawai yang mampu menyelesaikan pekerjaan dengan baik memiliki nilai rata-rata tertinggi dibandingkan dengan nilai rata-rata pada indikator lainnya. Sedangkan pada dimensi ekstrinsik dibuktikan pada hasil tanggapan responden pada indikator pemberian fasilitas $\left(\mathrm{X}_{216}\right)$ bahwa instansi memberikan fasilitas yang cukup kepada saya dalam bekerja.

Signifikannya pengaruh motivasi kerja $\left(\mathrm{X}_{2}\right)$ terhadap produktivitas pegawai disebabkan karena pegawai senantiasa menyelesaikan pekerjaannya sesuai dengan target yang telah ditentukan. Hal ini dibuktikan pada tanggapan responden pada indikator ketetapan waktu $\left(\mathrm{Y}_{12}\right)$ yaitu pada pernyataan bahwa Penyelesaian pekerjaan saya senantiasa sesuai dengan target yang telah di tentukan, memiliki nilai rerata tertinggi dibandingkan pernyataan lainnya dalam indikator ketetapan waktu. Mendukung temuan Budiartha dkk.,(2015) bahwa motivasi kerja berpengaruh positif signifikan terhadap produktivitas kerja Aparatur Sipil Negara

\section{c) Pengaruh variabel yang dominan Motivasi terhadap kinerja pegawai}

Pengujian variabel yang dominan dilakukan dengan membandingkan nilai t-statistik atau t-hitung antara pelatihan (training) sebesar 1,558 dengan t-hitung pada variabel motivasi sebesar 10,717 . Sehingga dengan demikian variabel yang dominan mempengaruhi kinerja pegawai adalah motivasi karena nilai t-hitung pelatihan < dibandingkan t-hitung motivasi. Sehingga hipotesis $\left(\mathrm{H}_{3}\right)$ diajukan bahwa motivasi merupakan variabel yang dominan berpengaruh terhadap produktivitas kerja pegawai BPS di Sulawesi Selatan, terbukti diterima. Hal ini juga di buktikan dengan hasil uji kontribusi dimana pelatihan $\left(\mathrm{X}_{1}\right)$ memberikan kontribusi terhadap produktivitas kerja (Y) sebesar 0.029 atau 2.90\% sedangkan motivasi $\left(\mathrm{X}_{2}\right)$ memberikan kontribusi sebesar 0.576 atau $57.60 \%$ sehingga dapat dinyatakan bahwa total kontribusi yang diberikan oleh variabel independent terhadap variabel dependent sebesar $2.90 \%+57.60 \%=60.40 \%$

Hasil ini disebabkan karena motivasi yang berdasarkan fakta lapangan yang ada, menunjukkan bahwa penerapan motivasi yang diberikan oleh BPS telah dilakukan secara baik, tepat dan mampu

Halaman 79 


\section{JURNAL ORGANISASI DAN MANAJEMEN}

Issue 1 (Agustus, 2018)

mempengaruhi pegawainya untuk dapat meningkatkan produktivitasnya secara efektif maksimal dalam mencapai tujuan organisasi/instansi. Kemudian hasil temuan dari Riyan Saputra Alam (2014), bahwa variable pelatihan berpengaruh positif dan tidak signifikan terhadap peningkatan kinerja. Variable motivasi berpengaruh positif dan signifikan terhadap peningkatan kinerja. Variabel yang paling dominan terhadap peningkatan kinerja adalah variabel motivasi.

\section{Kesimpulan dan Saran}

Berdasarkan nilai koefisien determinasi menunjukkan nilai adjusted $\mathrm{R}^{2}$ sebesar 0.604. Hal ini menunjukkan bahwa variabel bebas (independen) yaitu pelatihan,motivasi dalam penelitian ini mempunyai kontribusi sebesar 60,40\% terhadap variabel terikat (dependen) yaitu produktivitas kerja. Sisanya sebesar30,40\%dipengaruhi oleh faktor-faktor lain yang tidak di jelaskan dalam penelitian ini. Hasil pengujian secara parsial pada uji t menunjukkan bahwa pelatihan berpengaruh positif signifikan terhadap produktivitas kerja pegawai dengan nilai t-hitung lebih kecil dari t-tabel $(1.558<1,988)$ dan nilai signifikan lebih lebih kecil dari $0.05(0,123>0.05)$, hasil penelitian ini mengindikasikan bahwa pelatihan yang diberikan oleh instansi kepada pegawai belum bisa memberikan kontribusi nyata kepada pegawai sehingga belum mampu meningkatkan produktivitas kerja secara optimal.

Hasil pengujian secara parsial pada uji t menunjukkan bahwa motivasi berpengaruh positif signifikan terhadap produktivitas kerja pegawai, dengan nilai t-hitung lebih besar dari t-tabel $(10,717>1,988)$ dan nilai signifikan lebih kecil dari $0.05(0,000<0.05)$,hasil penelitian ini mengindikasikan bahwa semakin tinggi motivasi yang diberikan oleh instansi maka akan mampu meningkatkan produktivitas kerja pegawai dalam menyelesaikan pekerjaannya.

Disarankan Untuk penelitian selanjutnya peneliti menyarankan agar menggunakan variabel-variabel independen lain yang dapat mempengaruhi variabel produktivitas, mengingat bahwa dalam penelitian ini kontribusi variabelpelatihan dan motivasi sebesar $60,40 \%$ terhadap produktivitas kerja yang artinya bahwa kedua variabel ini sudah terbukti mempunyai pengaruh yang cukup tinggi. Perlu dilakukan penelitian lebih lanjut dalam mengkaji pemberian pelatihan dan motivasi terhadap produktivitas kerja untuk skala lebih besar dari sisi sampel maupun jenis instansinya.

\section{Referensi}

Alimuddin. 2015. Pengaruh Motivasi Terhadap Produktivitas Kerja Karyawan Pada Pt Putra Bintan Borneo Timur Di Samarinda. eJournal Ilmu Administrasi Bisnis, 2015, 3 (4): 795-805 ISSN 2355-5408

Bahar, A., dan Sjahruddin, H. 2015. Pengaruh Kualitas Produk Dan Kualitas Pelayanan Terhadap Kepuasan Konsumen Dan Minat Beli Ulang. JURNAL ORGANISASI DAN MANAJEMEN, 3(9), 14-34.

Budiartha, I. G. N., Bagia, I. W., dan Suwendra, I. W. 2015. Pengaruh pelatihan dan motivasi kerja terhadap produktivitas kerja karyawan. Jurnal Jurusan Manajemen, 3(1).

Danang, Sunyoto. 2012. Manajemen Sumber Daya Manusia. Jakarta: PT Buku. Seru

Halaman 80

Authors : Andi Pettarani dkk. Issue 1 (Agustus, 2018); 66 81 


\section{JURNAL ORGANISASI DAN MANAJEMEN}

Issue 1 (Agustus, 2018)

Fauzi, M. 2009. Metode Penelitian Kuantitatif, Semarang: Walisongo Press, Hartatik , Indah Puji. 2014. Buku Praktis Mengembangkan SDM, Jogjakarta

Hasibuan, Malayu S.P 2007, Manajemen Sumber Daya Manusia Perusahaan,. Bandung, PT. Bumi Aksa

Hasibuan, Malayu S.P.. 2010. Manajemen Sumber Daya Manusia. Jakarta. PT Bumi Aksara.

Hijrah, Sjahruddin, H., dan Heslina. 2017. Pengaruh Penempatan dan Keterlibatan Kerja Terhadap Kinerja Karyawan Pada PT. Bank BNI (Persero) Tbk Cabang Makassar. E-Library STIE YPBUP Bongaya, 1(1), 1-14.

Hikmawati, Sjahruddin, H., dan Themba, O. S. 2016. Loyalitas Nasabah Tabungan: Peran Nilai dan Kualitas Hubungan. E-Library STIE YPBUP Bongaya 2016, 2(2), 80-93.

Kaswan, 2011. Pelatihan dan Pengembangan untuk Meningkatkan Kinerja SDM, Alfabeta, Bandung

Komara, A. H., dan Luwis, A. 2017. Pengaruh Pelatihan Dan Pengalaman Kerja Terhadap Produktivitas Karyawan Pada CV. Roda lintas katulistiwa pekanbaru. Procuratio (Jurnal Ilmiah Manajemen), 4(1), 11-22.

Mangkunegara, A.A. Anwar Prabu. 2009. Manajemen Sumber Daya Manusia. Bandung: PT. Remaja Rosdakarya

Martoyo, S. 2007. Manajemen Sumber Daya Manusia. Yogyakarta: BPFE

Mathis, Robert. L dan Jackson John. H, 2001. Manajemen Sumber Daya Manusia, Jilid 1, Salemba Empat, Jakarta.

Riyan, Saputra Alam. 2014, Pengaruh Pemberian Pelatihan Dan Motivasi Terhadap Peningkatan Kinerja Karyawan pada PT.PLN (PERSERO) Area Pengatur (APD) Makassar

Robbins, Stephen P. dan Timothy A. Judge. 2008. Perilaku Organisasi Edisi ke12,Jakarta: Salemba Empat.

Safitri, E. 2013. Pengaruh Pelatihan Dan Disiplin Kerja Terhadapkinerja Karyawan. Jurnal Ilmu Manajemen (JIM), 1(4).

Saksono, Slamet. 2008. Administrasi Kepegawaian. Yogyakarta: Kanisius

Sedarmayanti, 2013, Manajemen Sumber Daya Manusia, Bandung: Refika. Aditama.

Sedarmayanti. 2009. Sumber Daya Manusia dan Produktivitas Kerja. Bandung: CV. Mandar Maju.

Sugiyono. 2014. Metode Penelitian Kuantitatif Kualitatif dan R\&D. Bandung : Alfabeta.

Suwanto, H., dan Priansa, J. Donni, 2011. Manajemen Sumber Daya Manusia Dalam Organisasi Publik dan Bisnis.

Authors : Andi Pettarani dkk. Issue 1 (Agustus, 2018); 66 81 